\title{
A foundation for foundation phase teacher education: Making wise educational judgements
}

\begin{abstract}
We start our paper with a critical exploration of the current 'back to basics' approach in South African foundation phase teacher education with its emphasis on strengthening the teaching of subject knowledge. We claim that such a proposal first demands an answer to the question 'what is foundational in foundation phase teaching?' We propose an answer in three stages. First we argue that teacher education should be concerned not only with schooling or qualification (knowledge, skills and dispositions) and socialisation, but, drawing on Gert Biesta's work, also with subjectification (educating the person towards the ability to make wise educational judgements). Secondly, these three aims of education lead to five core principles, and we finish by showing how these principles inform our storied, thinking and multimodal/semiotic curriculum. Our answer to our leading question is that pedagogical 'know-how' and views of 'child' and 'childhood' constitute the subject knowledge that is foundational in the foundation phase curriculum.
\end{abstract}

Keywords: Teacher education, childhood studies, foundation phase teaching, aims of education, child and childhood, making wise educational judgements

Karin Murris, University of Cape Town. Email: Karin.murris@uct.ac.za.

Clare Verbeek, University of Cape Town

South African Journal of Childhood Education | 2014 4(2): 1-17 | ISSN: $2223-7674$ |๔ UJ
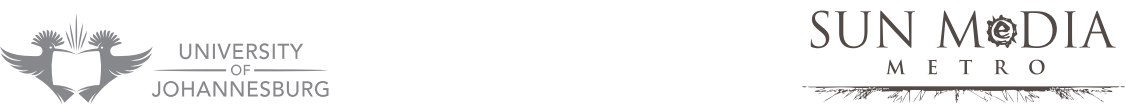


\section{Introduction}

Concern for improving the quality of schooling in general, and during the early years/ foundation phase in particular, leads us to consider what is basic, foundational, and essential in teacher education programmes. A range of complex explanations and solutions have been advanced for the continued poor performance of South African students at all levels on national and international benchmark tests (Bloch 2009; Fleisch 2008; Soudien 2007; Taylor 2008). One argument that is gaining increasing traction is that the country's teachers are deficient in 'content' knowledge and that greater emphasis should be placed on 'the basics' of developing teacher knowledge (Shalem \& Hoadley 2009; NEEDU 2013; Taylor \& Taylor 2013; Hoadley 2012). Alongside this, the latest in a series of revisions and (re)presentations of the National Curriculum Statement (RSA DBE 2011) is providing teachers with highly prescribed, specified, sequenced and paced guidance regarding the content that should be taught in schools and how this should be done. In addition, teacher guides for text books and materials produced by the Department of Education increasingly provide teachers with scripted lessons in an attempt to cover for a lack in teachers' subject content and pedagogic content knowledge. Such scripted lessons remove agency from the teacher (Ebrahim, Verbeek \& Mashiya 2011).

In this article we argue that focusing on subject content and pedagogic content knowledge in teacher education is absolutely necessary, but quite insufficient. We need to focus on what teachers know and on what they do. Carefully considering the purpose of education in general, we propose that it is also crucial in foundation phase teacher education to pay attention to the (trans)formation of the (student) teacher as a person or subject who can and should make wise educational decisions. We conclude by offering some pointers as to how this may be achieved by, inter alia, including Childhood Studies as a subject in initial teacher education programmes.

\section{Aims of education}

In answering the question "What are the foundations of foundation phase teacher education?', it is helpful to turn to the writings of contemporary philosopher of education Gert Biesta. In a sense, he shares the concern about what is described in the introduction as the disappearance of knowledge in schooling. Biesta (2010) refers to this phenomenon when he notes what he calls the 'learnification' of educational discourse and practices, and explains that the global shift towards talking about 'learning' rather than 'education' has meant a moving away from concerns about what content is taught to concerns about process (skills and competences). Teaching, he claims, is always about content, that is, about something for particular purposes, and it is always relational, because it involves someone educating somebody else (Biesta 2012b:12). His main point is that the language of learning in teacher education ('learnification') hides the importance of content, purpose, and the 'who' or subjectivity of the teacher in the educational relationship (Biesta 2006, 2010, 2012a). 
Biesta argues that teacher education works in three domains and has three concurrent, overlapping aims. It should therefore be concerned not only with qualification (gaining the knowledge, skills and dispositions that qualify us to teach something) and socialisation (transmitting the values and traditions that enable teachers to live and work within existing social orders and do as teachers are expected to do), but also with how education impacts on the person (see Figure 1)', which he refers to as subjectification. Although each aim of education is legitimate, Biesta does prioritise: foundational for education is the formation and transformation of the person. It is on this basis that questions about knowledge, skills and dispositions, competence and evidence can be asked.

\section{Figure 1: Gert Biesta's three aims of education}

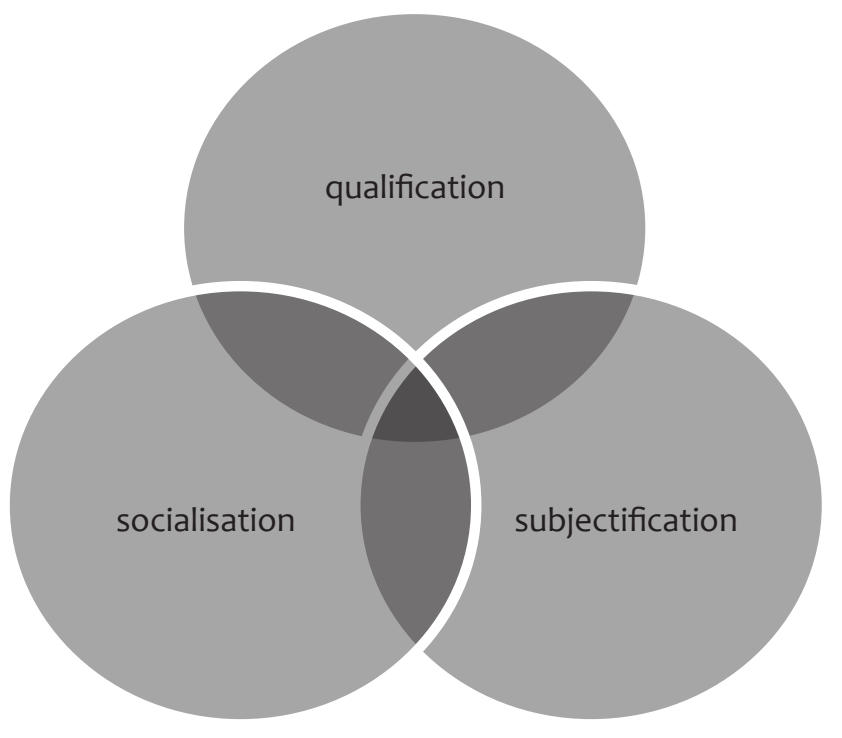

\section{Subjectification and making wise educational judgements}

"Subjectification" is the formation and transformation of students and teachers into "subjects" (Biesta 2010:21), by which Biesta means teachers and ultimately the children they teach coming into presence as individuals, as independent agents actively shaping society. Education's aim of socialisation is different from that of subjectification. The former is about becoming part of an existing order and the creation of an identity through identification with that order. Subjectification, on the other hand, is guided by freedom and is about existence "outside" such orders (Biesta 2012b:13). Neither is subjectification a skill or a competence; rather, it is a quality of a person. Biesta suggests that this aim of education is about speaking with one's own unique ${ }^{2}$ voice and bringing 
something new into the world. He regards teaching as 'a gift' that is given and received to bring about something new (Biesta 2013).

Subjectification has to do with acting in a public space (Biesta 2006), taking responsibility for our actions, and making wise educational judgements. Making situated, wise judgements, usually in the heat of the moment in the classroom, is at the heart of what teachers do. While knowledge about 'what works' can inform what happens in classrooms, it can never replace judgements about what needs to be done. It is precisely this aspect of teacher development that we feel is underplayed in South Africa and sacrificed in the quest for teacher knowledge and curriculum delivery, and which we argue should be addressed upfront in teacher education programmes.

\section{Formation of the person towards educational wisdom}

How then does the student teacher transform towards making wise educational decisions? We consider first Biesta's two propositions about this, and add to these proposals inspired by our work in initial teacher education for the foundation phase.

Biesta (2013) argues that we can develop the ability to make wise (virtuous) educational decisions only by doing it. Teachers make situated judgements about what is educationally desirable in each of the three dimensions of educational aims. This cannot be handed out in lectures as templates or prescribed through textbooks. Similarly, for Dewey the making of judgements cannot be learnt by telling or instruction, but is "cultivated by student reflection rather than impressed upon the student by moral authority from without" (Cam 2012:33). Biesta's proposed aim of subjectification justifies the inclusion in a foundation phase teacher education curriculum of subjects such as critical reasoning and the arts (the nurturing of creative constructions and imaginative representations of knowledge).

Student teachers need multiple opportunities to practice making educational judgements, as well as opportunities to reflect individually and together about this experience. Therefore, in our teacher development work, we expose our students to many opportunities to practice making educational judgements in different situations (in real classrooms, in the relatively safe environment of the university, and in assignments and tutorials).

Secondly, Biesta (2013) argues that we learn to make wise judgements by carefully observing how others make virtuous decisions and by talking to them about their decisions, as well as by studying images of teachers in literature and culture. Observation of experienced teachers in real life and also digitally is a traditional part of all teacher education programmes in South Africa, and we use this as an opportunity to focus on how and why teachers decide what to do in the heat of the moment.

We argue that the key educational resource at the teacher's disposal is him- or herself as a person who mediates in any concrete moment between child and curriculum when making practical judgements. ${ }^{3}$ Therefore, in addition to Biesta's propositions, we suggest that not only knowledge about curriculum, but, especially in the foundation phase, knowledge about the foundation phase child is critical (for example, knowledge about 
what a child can be expected to achieve in terms of reasoning, morality, subject knowledge acquisition, etc). It is this claim to knowledge about child that has been deconstructed (for example Burman 2008) and reconstructed (for example Lenz-Taguchi 2010) in the last two decades from a philosophical (Matthews 1994; Kennedy 2013; Kohan 2002; Haynes \& Murris 2012); sociological (Dahlberg, Moss \& Pence 2013); cultural-historical, postmodern, poststructuralist and feminist perspective (Nolan \& Kilderry 2010).

\section{Shifting ideas about child and childhood and the case for childhood studies}

Through their own experience and memories of being a child, sibling, and perhaps a parent, our current student teachers have been socialised in particular hegemonic discourses about child and childhood. During their initial teacher training, students' role models are the teachers they encounter in teaching practice, but often teachers' unexamined beliefs about the young child, their own school experiences and deep seated emotions, connected with freedom, control, power and social status, influence how they conceptualise education - what is worthwhile and who is worth listening to from an epistemic perspective (Murris 2013). It is crucial for subjectification that (student) teachers learn about 'developmentalism', the essentialisms involved, and the implied generalisations about what individual children as a matter of fact are capable of as a result of existing age prejudice. Knowledge about shifting views of child and childhood should be a core component in foundation phase teacher education (for example, by including a subject such as Childhood Studies in the curriculum). Opening up new ways of thinking about child, also outside of the academic world, will make different educational practices and relationships possible and could allow student teachers to speak with their own voice, rather than speak with a voice that represents the still dominant developmental discourse. The close relationship between conceptions of child and teachers' expectations of children's intellectual capabilities needs to be a focus of attention in teacher education programmes.

In between child and curriculum there is a pedagogical space that is informed by adults' attitudes about knowledge, but also about children, and the two are of course closely related 4 (Haynes \& Murris 2012). Ideas about children are constantly changing and especially in the last two decades there have been major shifts in research, laws, policy and practices. Phil Jones suggests that seeing children "not as proto-adults or as the property of parents" (2011:6), but in their own right and as having rights is the driving force behind the contemporary re-examination of adults' attitudes towards children, a continuum which he summarises succinctly in Table 1 below (ibid:29). 
Table 1: Emerging and traditional attitudes to children

\begin{tabular}{|c|c|c|}
\hline $\begin{array}{c}\text { Emerging view } \\
\text { The child as: }\end{array}$ & $\begin{array}{c}\text { Traditional approach } \\
\text { The child as: }\end{array}$ \\
\hline capable & rather than & incapable \\
\hline active & rather than & passive \\
\hline visible & rather than & vulnerable and needy \\
\hline powerful & rather than & $\begin{array}{c}\text { seen and attended to as } \\
\text { an investment for the future }\end{array}$ \\
\hline $\begin{array}{c}\text { valued and attended to } \\
\text { in the present }\end{array}$ & rather than & $\begin{array}{c}\text { a mini-adult lacking in full } \\
\text { adult capacities }\end{array}$ \\
\hline an individual with their \\
own capacities
\end{tabular}

Jones points to the difficulty of implementing and incorporating these changing ideas about child in practice, especially in families and societies that are patriarchal. Moreover, there is still an almost unquestioned link in education between curriculum construction and psychological theories of child development (File, Mueller \& Basler Wisneski 2012).

The developmental orientation is informed by a number of theories about physical and psychological development, but although current thinking emphasises socio-cultural context in child development, in teacher education, students are still routinely socialised into fixed beliefs about children's cognitive development through irreversible stages and 'key milestones' (see, for example, Cooper 2010; Whitebread 2012). There is a conceptual confusion in contemporary education that is very resilient: the mind is understood as if it were a physical body that grows 'naturally' and matures in stages (Murris 1997; Egan 2002: 79-82). For many early educators and teacher educators, the aim of early years' education programmes is still to prepare children for various aspects of schooling ('schoolreadiness'). The common classification of foundation phase as a time when children 'learn to read' before they move into upper primary school, where they 'read to learn', is evidence of this readiness approach.

In her research into how contemporary textbooks at teacher training institutions position child, Hatch concludes that child development theory strongly influences "the materials, programs, and policies that drive the early childhood education mainstream" (2012:43). This 'DAP brand', as she calls it, is carefully marketed by the American National Association for the Education of Young Children (NAEYC) and adopted by "countless programs, policies and products in the US and around the globe" (ibid). Hatch points out one major problem of this dominance: developmental theories do not offer any information about the 'what' of a curriculum, that is, "the substance of early childhood curriculum cannot be logically identified" on the basis of psychology (ibid:44). Curriculum guidance materials clearly indicate this. Development is measured in terms of processes and skills, but not in terms of content knowledge. In our introduction, we mentioned the problems with educational achievement in the South African foundation phase. Hatch's observation could be significant in that the 
dominant discourse of developmental psychology has hidden the need to be more specific about content knowledge.

Kieran Egan points out another problem with conceiving of development as a largely linear process "of increasing differentiation that recognizes no losses attached to cognitive gains" (2002:105; see also footnote 1). He argues that it is not clear to what extent this biological model is descriptive or prescriptive, that is, "when someone describes 'the developmental process', we have to ask how far they are giving us an account of some natural, spontaneous process, or how far they are describing a process shaped by our previous educational prescriptions" (ibid:79-80). So the argument is this: even if it were true that children's minds develop, grow and mature like a physical thing in the world, it still needs to be argued that developmentalism is indeed desirable as an educational theory, especially as the implications for practice in the early years are profound - the metaphor shapes how educators perceive children as thinkers (Murris 1997), how they regard the purpose of play, and, more generally speaking, how they theorise their role as pedagogues.

Denaturalising childhood is linked to the 'linguistic turn' in the history of ideas (Taylor 2013). A further shift in theorising child and childhood is the contemporary 'material turn', which attributes agency (also) to the material world and problematises all binary opposites, including the theory/practice, child/adult and nature/culture divides. Lenz-Taguchi (2010) shows the profound implications this has for pedagogy and content in schools and universities. Learning does not take place 'in' the child, but in the space 'between' the person as embodied organism and the material world (for example the furniture in the room, the clay in her hand, the picture book on the table), taking into account the situated time-space relations between all material organisms that act upon each other. A relational materialist approach is critical of the "anthropocentric gaze", that is, "a gaze that puts humans above other matter in reality", and the idea that language constructs reality as it "reduces our world to a social world, consisting only of humans and neglecting all other non-human forces that are at play" (Hultman \& Lenz-Taguchi 2010:526). This posthumanist thinking has profound implications for observing children and research in early childhood education.

\section{Five principles for teacher education}

Thus far we have presented a case for focussing on the subjectification of student teachers and, expanding Biesta's ideas for how to prepare them to make wise educational judgements, we have argued for the inclusion of Childhood Studies in the curriculum for initial development of foundation phase teachers. The purpose of Childhood Studies is for students to learn the required skills and knowledge (qualification) to socialise into practices that position child as citizen, not as citizen-to-be, and to be critical of the idea of the abstract, individual child of developmental psychology that informs current school and teacher education curricula, policies, and school practices. We therefore introduce our students to pedagogies and educational approaches that express post developmental views of child (Nolan \& Kilderry 2010) 
without pre-empting what these might be. These approaches form a general basis from which the specific content of the curriculum can be developed. Three of these pedagogical approaches are discussed in the next section after a brief consideration of the pedagogical principles which frame our teacher education curriculum and guide the (student) teacher when making pedagogical choices.

The first of these, echoing the South African Constitution and the general aims of the National Curriculum and Assessment Statement, is an ethico-political commitment to participatory democracy and social justice. When making pedagogical choices we treat students/children as democrats capable of deliberation (Linington, Excell \& Murris 2011). We propose that teachers be 'in authority', rather than authoritarian, and that they listen to children as if they are knowledge bearers, respecting fantasy and emotion as forms of knowing. Second, we make choices for intellectual integrity, a notion which cuts across various axes: the relationship theory/practice, our teaching/ that of our students in class, content/form, the various subjects in the National Curriculum, etc. We explicitly explore how the various parts of the curriculum relate to each other and constitute a coherent whole, and at the same time remain open to embrace an unknown future (after all, many new theories and practices will emerge). Third, the principle of reflexivity captures our belief that both student teachers and their future pupils learn through cycles of experience, reflection and action. We value students' and children's thinking, researching and reasoning, and use this as a basis for understanding their learning, providing structured metacognitive opportunities for review and reflection, as well as assessment for and of learning.

Narrativity is the next pedagogical principle that guides our programme. This feeds into imagination and curiosity. Inspired by Kieran Egan (1988; 1992), we assume that narratives help fix the emotions and therefore aid memory, motivation and engagement. Without introducing a dichotomy between reason and imagination, Egan argues that narratives set up a dialectical activity between the familiar and the everyday by featuring the extremes of reality and the limits of experience (Egan 1992). So, although Egan agrees with Dewey that a curriculum should start with children's/ students' own experiences, interests or environment - an idea that has led to the now mainstream "expanding horizons curriculum" (Egan 1995:119) - he stresses that, especially in the foundation phase, these experiences should also include children's knowledge of abstract concepts. Egan argues that although children's thinking is to a large extent concrete, it does not follow that therefore curriculum content should be presented in concrete terms. Through narratives, young children "deploy easily and readily the most abstract ideas we ever learn" (ibid:118): ideas about good/evil, ugly/ beautiful, strong/weak, etc - the binary concepts that structure narratives and are deeply felt by young children.

Finally, we include the principle of aesthetic and embodied learning. Learning takes place in the space between people and between people and the material world. People use their bodies for making meaning. This means that space, time and the material environment for learning are important when teaching children and students, so the curriculum needs to include selecting and creating good quality and aesthetically 
pleasing materials (including texts and consideration for the built environments in which learning takes place).

\section{Play-based learning for all ages}

We have argued that theories of child and childhood produce particular pedagogical practices, and agree with Dahlberg, Moss and Pence (2013:56) that "pedagogical work is the product of who we think the young child is". Developmental child theories have influenced how learning through play is theorised: the resource-rich environment is prepared in such a way that the self-directed child's needs are met (Nolan \& Kilderry 2010). A substantial part of the subject Childhood Studies is therefore focused on play, what it is, and how a particular approach to play can make the teaching of the so-called 'basics' (mathematics, literacy, life skills) engaging, motivating and memorable.

The concept of play escapes clear definition. We propose a conception of play that deconstructs binary opposites such as the theory/practice and the child/adult divide. MacIntyre Latta (2013) suggests that play is not just the domain of young children, but involves ageless minds that are curious, flexible, open-minded, earnest and willing to try things out. Her notion of aesthetic play is an attractive one. Drawing on Gadamer and Dewey, she conceptualises play as a process that makes it possible to think and do otherwise and offers opportunities to change, build and make meaning - as a way of being-in-the-world, revealing "its own order to which one surrenders" and involving "total absorption" (ibid:xiii;105). Play involves "a seeing that is multi-sensory" that prompts "prior understandings that reinforce and fold into one another, and contribute to a connected whole" (ibid:8-9). Adopting this notion of play, we propose a play-based curriculum - also with student teachers - that has a thinking, storied and semiotic focus.

\section{A thinking curriculum}

Philosophy for Children ( $\mathrm{P} 4 \mathrm{C}$ ) is an approach to teaching and learning created by Matthew Lipman, a North American philosophy professor at Columbia University, who was concerned because many of his students seemed unable to think for themselves or to make careful and reasoned judgements. He believed that even young children wonder about deep philosophical questions and can learn to think like philosophers, and that if philosophical enquiry were part of the school curriculum, children would become better thinkers and be better prepared to be citizens of a democracy - a radical idea when Lipman first proposed it in the 1970 s.

Lipman did not base $\mathrm{P} 4 \mathrm{C}$ on psychologists' theories of intelligence and intellectual development, but on the value of philosophy as a human activity and a particular view of childhood. The community of enquiry pedagogy of $\mathrm{P} 4 \mathrm{C}$ can be a powerful tool for interrupting normalised discourses about children, as it facilitates "seeing individuals before seeing children" (Kennedy 2013:4). Some P4C practitioners and theorists in particular (for example Kennedy, Kohan, Haynes and Murris) use P4C as a means to work more democratically in early childhood settings and underline the fallibility of the 
teacher in genuinely open-ended enquiries with children. The skill of listening without prejudice - not as though we already know and understand what is about to be said - remains a challenge, especially as young children's thinking can be so imaginative and fantastical. As a result, philosophical enquiries with young children entail a very playful, exploratory and imaginative form of philosophising (Haynes \& Murris 2013), which we extend to the university classroom.

$\mathrm{P} 4 \mathrm{C}$ is used in our teacher education curriculum as a topic, so student teachers learn how to do philosophical enquiries with children, but when appropriate, we also use it in the university classroom as a method for teaching the core methodology subjects. The generic pedagogical skills student teachers learn are listening, questioning, enquiring, observing, and thinking for oneself through thinking with others. The purpose of learning these more generic skills is the overall aim of subjectification - we want our students to have the competence and confidence to make independent, situated and reasonable educational judgements. Finally, the pedagogy also makes it possible for us to work reflexively and democratically as a community of thinkers at the university, so we also use the community of enquiry pedagogy as a research instrument to evaluate our programme (an ongoing participatory action research project).

\section{Semiotic curriculum}

Art and stories draw on people's emotions and engage with the imagination. They also require critical and reflexive thinking. Visual art, craft, physical movement, music, dance, drama, literature and the aesthetic environment are the contexts of our play-based learning, offering creative opportunities for our students to explore their inner as well as outer worlds using all their senses. For subjectification, it is essential to teach them basic creative skills and knowledge of the arts, so that they change as people and become artists. Our students need to be able to support the aesthetic construction and expression of content knowledge in thought-provoking, safe, stimulating and well-organised learning environments. The university classroom should be an environment where people can exercise choice and have structured open-ended opportunities to explore the consequences of their words and actions through the embodied activities so characteristic of the arts.

An aesthetic, embodied approach to teaching and learning called 'Reggio Emilia' was far ahead of its time and the aim of subjectification makes it possible to justify the use of its philosophy and methods in our curriculum. Reggio Emilia is a small prosperous town in Northern Italy and the birthplace of the educational philosophy of Loris Malaguzzi, who saw education as a shared process of knowledge co-construction (not transmission) - a situated political and educational response to Italy's fascism during the Second World War. In collaboration with a group of women who wanted to combine work with good quality care for their young children, an early childhood theory was developed and enacted that put critical thinking and collaborative learning at the heart of building a democratic society (Malaguzzi 1998). Importantly, Reggio Emilia is a grounded and situated philosophy that assumes high expectations of 
children, parents and members of the community, and as such cannot be imitated elsewhere. Nevertheless, the principles of this imaginative and inclusive approach to education have had considerable influence globally (notably in the US, Scandinavia and Oceania) and the corporal turn has made Reggio Emilia relevant for many posthumanist, postmodern, poststructuralist and postdevelopmentalist educators and educationalists. The idea that it could be used creatively by teachers and teacher educators in South Africa to help build democratic foundations for South African's foundation phase curriculum is an exciting prospect.

We are contrained by space in this article to mention only three key ideas of Reggio Emilia. First, the idea of 'The Hundred Languages' of children refers, on one (practical) level, to the introduction of semiotic tools such as visual arts, physical movement, video, digital cameras and computers for meaning-making in schools. At a symbolic level, the hundred languages are, as Carla Rinaldi puts it,

[A] metaphor for crediting children and adults with a hundred, a thousand creative and communicative potentials...[it] represents a strategy for the construction of concepts and the consolidation of understanding. But above all it is a declaration of the equal dignity and importance of all languages, not only writing, reading and counting, which has become more and more obviously necessary for the construction of knowledge

(Rinaldi 2006:175)

Creativity exists in all languages, including mathematical and scientific languages (Rinaldi 2006). Reggio-inspired schools employ artists/art-educators (atelieristas) who work alongside teachers (pedagogistas) and help create the right environment (the environment as the 'third teacher') for extended project work (progettare), where new knowledge takes shape through action and classrooms (ateliers) become metaphorical places where "brains, hands, sensibilities, rationalities, emotion and imagination all work together" (Vecchi 2010:2). This extended project work is the second aspect of Reggio that we have been inspired by in our teacher education curriculum design.

Thirdly, we have adopted the core Reggio Emilia idea of pedagogical documentation with our students (with the idea that they will also do this with their learners). This kind of documentation is both content and process (Dahlberg et al 2013). It is unlike 'normal,' traditionally enacted child or student observations, whereby a person is observed and assessed in terms of a set of preconceived standards. Instead, the ideal of representing 'reality-as-it-is' is abandoned and educators accept that all descriptions actively involve the observer, hence all documentation involves self-reflexivity (ibid): as perceivers we inscribe our own norms and values into the process. Documentation is a concrete, visual, and sometimes audible means to record what students say and do, for example, through note-taking, photography and film, or art constructions. At the same time, this material can be used as formative assessment in that it offers concrete opportunities for students to democratically reflect on their learning by including them. Instead of the involvement of parents and other teachers in this process, as in Reggio schools, we involve the team of lecturers who co-teach and the students' mentor teachers in the partnership schools. 
What philosophical enquiry (P4C) and Reggio Emilia (RE) have in common is a particular epistemology and ethics. In $\mathrm{P} 4 \mathrm{C}$ and project work (RE) knowledge acquisition is assumed to be not linear, but organic and without an overall ordering principle that has roots, trunks and branches like a tree (Rinaldi 2006). It advances more like a sailing boat trying to tack into the wind (Lipman 1991:15-16), making progress by moving from side to side. Both approaches regard children and their teachers as competent, responsible agents and active enquirers. Reggio Emilia in particular constructs schools as pillars of the local community (Edwards, Gandini \& Forman 1998).

\section{A storied curriculum}

The narrativity principle guides us in creating resources for teaching. The more distant and strange a narrative is, the more a learner/student will be emotionally engaged, cognitively inspired, and intrinsically motivated to bring new understandings to the everyday and the familiar. A curriculum that takes the imagination seriously as an intricate part of the intellect should start with what is not familiar and therefore feature unusual characters (for example, mermaids, humans covered in body hair, aliens); extreme concepts (for example, immortality, the size of the universe); or obscure thought experiments. We frame our own teaching by creating imaginative problem-solving contexts that use narrative devices (see especially Egan 2006) which go beyond the teaching of one lesson and often include the various subject areas at the same time (in the same integrated manner we would like our students to teach). Moreover, we make complex educational theories and ideas more accessible by using visual devices, literature and metaphors. Contemporary picture books are particularly useful as a means to explore topics such as 'theories of emotion' (Murris 2009) or 'the positioning of child in texts' (Murris 2013) with student teachers. Our curriculum draws on a deep appreciation for good quality national and international children's literature, and our innovative use of picture books is only one example.

The narrative, arts and thinking frameworks outlined above form the foundations of our curriculum for foundation phase teachers. The different approaches mentioned inspire us to play with ideas, to play with various symbolic languages, and to play with narrative structures in our work with students. Above all, they make the learning of the curriculum not only more meaningful, but also more enjoyable and memorable.

\section{Conclusion}

We started this article by asking the key question, "What is foundational for foundation phase teacher education?', especially in the South African context. We have proposed three overlapping aims of education and suggest that the aim of developing the ability to make wise educational judgements (subjectification) should receive greater attention in teacher education programmes. We argue that the purpose of subjectification is connected with conceptions of child and childhood, which in turn influence how teachers mediate child and curriculum through the pedagogies they use. We have pointed out that developmentalism hides the importance of content in 
early childhood education, prescribes a particular approach to play, influences how we observe and listen to children, and shapes the questions we ask as educators. Moreover, it results in low expectations of children as thinkers. In order to disrupt those social constructions of child, we have suggested the inclusion of Childhood Studies as a core subject in foundation phase teacher education. Five intricately connected principles that form the foundation for our approach to play and pedagogy were briefly explored. We then outlined three approaches to teaching and learning that shape our own university teaching, but also model good classroom teaching. Students' bodies have to experience a thinking, storied and arts-based curriculum in order to fully appreciate the depth of embodied learning. There is no space in this paper to do justice to the centrality of the arts in our curriculum. We believe that the arts are essential for subjectification. The hand explores and represents the physical world (for example line, colour, motion) as well as the world of ideas. Much of thought is non-verbal and relational, and the use of the body can assist in the development and communication of these ideas - through, for example, the use of a musical instrument, puppetry or construction - and help us as teachers to speak with our own voice. We have shown how new directions of child subjectivity suggest that the material world and all our senses should be included in learning. We suggest that an emphasis on reasoning with children through philosophy, the normalisation of disagreement, and treating children as competent, active and responsible agents can help build robust, resilient and reasonable individuals in an embodied, relational manner. On the basis of such an conceptualisation of child and education we believe that the foundation phase (student) teacher will be better equipped to make wise judgements in teaching children to read, write, do mathematics and explore their world with a sense of wonder and engagement.

\section{References}

Bertram C. 2011. What does research say about teacher learning and teacher knowledge? Implications for professional development in South Africa. Journal of Education, 52:3-26.

Biesta GJJ. 2006. Beyond learning. Boulder, CA: Paradigm Publishers.

Biesta GJJ. 2010. Good education in an age of measurement: Ethics, politics, democracy. Boulder, CA: Paradigm Publishers.

Biesta GJJ. 2012a. Giving teaching back to education: Responding to the disappearance of the teacher. Phenomenology and Practice, 6(2):35-49.

Biesta GJJ. 2012b. The future of teacher education: Evidence, competence or wisdom? Research on Steiner Education, 3(1):8-21. [Retrieved 13 December 2013] www. rosejourn.com.

Biesta GJJ. 2013. Pragmatising the curriculum: Bringing knowledge back into the curriculum conversation, but via pragmatism. [Retrieved 17 December 2013] http://orbilu.uni.lu/bitstream/10993/10683/1/. 
Bloch G. 2009. The toxic mix: What's wrong with South Africa's schools and how to fix it. Cape Town: Tafelberg.

Burman E. 2008. Deconstructing developmental psychology. 2nd Edition. London: Routledge.

Cam P. 2012. Teaching ethics in schools: A new approach to moral education. Camberwell: Acer.

Campbell E. 2003. The ethical school. Maidenhead: Open University Press.

Cooper J. 2010. The Early Years Communication Handbook: A Practical Guide to Creating a Communication Friendly Setting. London: Practical Preschool Books.

Dahlberg G \& Moss P. 2006. Introduction: Our Reggio Emilia. In: C Rinaldi (ed). In Dialogue with Reggio Emilia. London: Routledge. 1-22.

Dahlberg G, Moss P \& Pence A. 2013. Beyond quality in early childhood education and care: Languages of evaluation. London: Routledge.

Dunne J. 1997. Back to the rough ground: Practical judgment and the lure of technique. Notre Dame, IN \& London: University of Notre Dame Press.

Dunne J \& Pendlebury S. 2003. Practical Reason. In: N Blake, P Smeyers, R Smith \& P Standish (eds). The Blackwell Guide to the Philosophy of Education. Oxford: Blackwell. 194-212.

Ebrahim HB, Verbeek C \& Mshiya NJ. 2011. Enabling roles to reclaim teacher agency: Insights from the Advanced Certificate in Teaching. Perspectives in Education, 29(4):58-65.

Edwards C, Gandini L \& Forman G. 1998. The hundred languages of children: The Reggio Emilia Approach - Advanced Reflections. 2nd Edition. Westport, CT: Ablex Publishing.

Egan K. 1988. Teaching as storytelling. An alternative approach to teaching and the curriculum. London, Ontario: University of Western Ontario.

Egan K. 1995 Narrative and learning: A voyage of implications. In: H McEwan \& K Egan (eds). Narrative in teaching, learning, and research. New York: Teachers College Press. 116-124.

Egan K. 1992. Imagination in teaching and learning; Ages 8-15. London: Routledge.

Egan K. 2002. Getting it wrong from the beginning: Our progressivist inheritance from Herbert Spencer, John Dewey, and Jean Piaget. New Haven: Yale University Press.

Egan K. 2006. Teaching literacy: Engaging the imagination of new readers and writers. Thousand Oaks, CA: Corwin Press.

File N, Mueller J \& Basler Wisneski D. 2012. Curriculum in early childhood education: Reexamined, rediscovered, renewed. London: Routledge.

Fleisch B. 2008. Primary education in crisis: Why South African schoolchildren underachieve in reading and mathematics. Pretoria: Juta.

Hatch JA. 2012. From theory to curriculum: Developmental theory and its relationship to curriculum and instruction in early childhood education. In: N File, J Mueller \& D Basler Wisneski (eds). Curriculum in early childhood education: Re-examined, rediscovered, renewed. London: Routledge. 42-54. 
Haynes J \& Murris K. 2012. Picturebooks, pedagogy and philosophy. New York: Routledge.

Haynes J \& Murris K. 2013. The realm of meaning: Imagination, narrative and playfulness in philosophical exploration with young children. In: P Costello (ed). Special Issue: Developing children's thinking in early childhood education. Journal of Early Child Development and Care, 183(8):1084-1100.

Hoadley U. 2012. What do we know about teaching and learning in South African primary schools? Education as Change, 16:187-202.

Hultman K \& Lenz-Taguchi H. 2010. Challenging anthropocentric analysis of visual data: a relational materialist methodological approach to educational research. International Journal of Qualitative Studies in Education, 23(5):525-542.

Jones P. 2011. Rethinking childhood: Attitudes in contemporary society. London: Continuum.

Kennedy D. 2006. The well of being, childhood, subjectivity and education. Albany, NY: State University of New York Press.

Kennedy D. 2013. Practicing philosophy of childhood: Teaching in the (r)evolutionary mode. Paper presented at the $16^{\text {th }}$ ICPIC Conference held at the University of Cape Town, 30 August-2 September.

Kohan W. 2002. Education, philosophy and childhood: The need to think an encounter. Thinking, American Journal of Philosophy for Children, 16(1):4-11.

Kristjansson K. 2007. Aristotle, emotions, and education. Aldershot: Ashgate.

Lenz-Taguchi H. 2010. Going beyond the theory/practice divide in early childhood education: Introducing an intra-active pedagogy. London: Routledge.

Linington V, Excell L \& Murris K. 2011. Education for participatory democracy: A Grade R perspective. Perspectives in Education, 29(1):36-46.

Lipman M. 1988. Philosophy goes to school. Philadelphia, PA: Temple University Press.

Lipman M. 1991. Thinking in education. Cambridge, MA: Cambridge University Press.

Macintyre Latta M. 2013. Curricular conversations: Play is the (missing) thing. London: Routledge.

Malaguzzi L. 1998. History, ideas, and basic philosophy: An interview with Lella Gandini. In: C Edwards, L Gandini \& G Forman (eds). The hundred languages of children: The Reggio Emilia Approach - Advanced Reflections. 2nd Edition. Westport, CT: Ablex Publishing. 49-99.

Matthews G. 1994. The philosophy of childhood. Cambridge, MA: Harvard University Press.

Murris K. 1997. Metaphors of the child's mind: Teaching philosophy to young children. Unpublished Phd thesis. Kingston upon Hull: University of Hull.

Murris K. 2000. Can children do philosophy? Journal of Philosophy of Education, 34(2):261-281.

Murris K. 2009. A philosophical approach to emotions: Understanding love's knowledge through 'Frog in Love'. Childhood and Philosophy, 5(9). [Retrieved 13 December 2013] www.periodicos.proped.pro.br/index.php?journal=childhood\&page=index. 
Murris K. 2013. Reading philosophically in a community of enquiry: Challenging Developmentality with Oram and Kitamura's Angry Arthur. Children's Literature and Education, 44(2) [Retrieved 13 December 2013] http://link.springer.com/ article/10.1007/s10583-013-9205-8\#page-1.

NEEDU (National Education Evaluation and Development Unit). 2013. The state of literacy teaching and learning in the Foundation Phase. NEEDU: Pretoria.

Nolan A \& Kilderry A. 2010. Postdevelopmentalism and professional learning: Implications for understanding the relationship between play and pedagogy. In: L Brooker \& S Edwards (eds). Engaging Play. Maidenhead: Open University Press. 108-122.

Rinaldi C. 2006. In dialogue with Reggio Emilia: Listening, researching and learning. London: Routledge.

RSA DBE (Republic of South Africa. Department of Basic Education). 2011. Curriculum and Assessment Policy Statement: Intermediate Phase. Pretoria: Department of Education.

Shalem Y \& Hoadley U. 2009. The dual economy of schooling and teacher morale in South Africa. International Studies in Sociology of Education, 19:119-134.

Soudien C. 2007. The 'A' factor: Coming to terms with the question of legacy in South African education. International Journal of Educational Development, 27(2):182-193.

Taylor A. 2013. Reconfiguring the natures of childhood. London: Routledge.

Taylor N. 2008. What's wrong with South African schools? Paper presented at What's Working in School Development Conference, JET Education Services, Boksburg, South Africa, 28-29 February.

Taylor N \& Taylor S. 2013. Teacher knowledge and professional habitus. In: N Taylor, S van der Berg \& T Mabogoane (eds). What makes schools effective? Report of the National Schools Effectiveness Study. Cape Town: Pearson.

Vecchi V. 2010. Art and creativity in Reggio Emilia: Exploring the role and potential of ateliers in early childhood education. London: Routledge.

Whitebread D. 2012. Developmental psychology \& early childhood education. London: SAGE Publications.

\section{Endnotes}

1. Interestingly, Canadian educationalist Kieran Egan also argues that there are three aims of education, but claims that they are inherently incompatible, as each purpose demands, for example, a different attitude towards assessment (qualification - the academic realm should not be assessed at all, but socialisation should, because we need to get it right). Egan derives his aims from describing how existing schools work (unlike his own philosophy of education). (See http://www.youtube.com/watch?v=0QFDzRkmiUE [retrieved 16 December 2013]). For Biesta, they are ideals, therefore normative. The third aim for Egan is Rousseau's introduction (deeply influenced by Spencer) to educational theory - the idea of children's natural development, which is not unlike Biesta's notion of subjectification, but there is no child agency or freedom, only a natural unfolding in what is 'there' innate and good 'in' the child at birth. (See Egan 2002.) 
2. Uniqueness here is not a property, essence or quality of an individual, but manifests itself in the relationship with others.

3. There is no space in this article to do justice to the complex topic of 'practical judgements 'or phronesis (Aristotelian). For Joseph Dunne and Shirley Pendlebury (2003), practical reason leads to wise actions only if the thinker exercises various virtues, such as reciprocity, mutual respect, openness, and a willingness to give reasons and to listen to others. The common thread is willingness to give and take. They understand phronesis as characterised by a habit of "salient focusing", which involves "the ability to see fine detail and nuance" - partly constituted by cognitive dispositions and partly by a person's perceptions of and emotional responses to situations (ibid:207-208). Emotions are involved in the perception (aisthesis) of the necessary details of a particular situation. Joseph Dunne and Kristjan Kristjansson insist that phronesis is not just the application of theories to particular cases (Dunne 1997). The implications for teaching are that the "teacher's capacity for reasoning cannot first be taught 'in theory' and then applied 'in practice'” (Kristjansson 2007:166).

4. Education is a deeply political and moral endeavour (Campbell 2003). No textbook or pedagogy is politically innocent. They make assumptions about adults and about children, what they can and cannot do, and what they should be able to do. They assume what knowledge is and who is in control of truth and meaning. 